\title{
Experiential knowledge, suffering, and vicissitudes of having malaria in the Brazilian Amazon: An ethnographic study
}

\author{
Luciane Machado Freitas de Souza ${ }^{a \star}$ \\ ${ }^{a}$ Interdisciplinary School of Health Sciences, Faculty of Health Sciences, University of Ottawa, Ottawa, \\ ON K1N 6N5, Canada \\ *lmach031@uottawa.ca
}

\begin{abstract}
This paper focuses on the multiple ways in which people who live along the rivers of the Brazilian Amazon, known as ribeirinhos, experience malaria outside of a clinical setting. It describes the local understanding of malaria, strategies to distinguish the illness from other febrile sicknesses, challenges for detecting the disease through biomedical diagnosis methods, and vicissitudes of having malaria. It draws on cases from ribeirinhos from a peri-urban community of Manaus and a rural community from Careiro, State of Amazonas, Brazil. Although malaria is biomedically characterized by the pathogens causing the disease, ribeirinhos have developed other standards to define malaria, including the intensity of the symptoms, the interval between the infections, and the types of medications dispensed to them. In the riverine communities studied, the etiology of malaria includes mosquitoes, microbes, water, wind, sun, and person-to-person transmission. Symptoms of malaria were found to overlap with other febrile sicknesses; hence, ribeirinhos developed skills to monitor how a malaise unfolds in their bodies. Experiential knowledge plays a key role in the early detection of malaria. Individuals who have no previous experience with malaria were found to spend more time seeking health care. Equally important, ribeirinhos perceive that malaria is part of the landscape they inhabit.
\end{abstract}

Citation: Freitas de Souza LM. 2017. Experiential knowledge, suffering, and vicissitudes of having malaria in the Brazilian Amazon: An ethnographic study. FACETS 2: 410-428. doi:10.1 I39/facets-2016-0063

Editor: Debra Clendinneng

Received: November 10, 2016

Accepted: March 29, 2017

Published: May 9, 2017

Copyright: (c) 2017 Freitas de Souza. This work is licensed under a Creative Commons Attribution 4.0 International License (CC BY 4.0), which permits unrestricted use, distribution, and reproduction in any medium, provided the original author(s) and source are credited.

Published by: Canadian Science Publishing

Key words: medical anthropology, malaria, ribeirinhos, experiential knowledge, local understanding, biomedical diagnosis, Brazilian Amazon

\section{Introduction}

Malaria is a parasitic disease transmitted to humans by female Anopheles mosquitoes infected with a pathogen, namely Plasmodium. Its occurrence in Brazil dates back to the colonial period (from the 14 th to 19th centuries), where malaria cases were reported in almost all areas of the country (Camargo 2003; Benchimol and da Silva 2008; Hochman 2009). Currently, malaria transmission occurs in the states of the Brazilian Amazon basin (Brasil 2003). The State of Amazonas, where I did my fieldwork, is $1559.161 \mathrm{~km}^{2}$ and is the largest territorial extension of Brazil. $98 \%$ of its area is covered by pristine forests, and it has one of the largest freshwater springs in the world (Governo do Estado do Amazonas 2016). It is estimated that 4001.667 people live in the State of Amazonas (IBGE 2016); it is the second most populous state of the Amazon region (IBGE 2016). Approximately $20 \%$ of the population lives in a rural setting; $30.78 \%$ of the total population live in poverty, $16.43 \%$ live in extreme poverty, and $24 \%$ of children live in extreme poverty (Programa das Nações Unidas para o Desenvolvimento 2014). Malaria stands out as the main 
infectious disease in the state. Within the populations who inhabit the State of Amazonas, riverine people, commonly called ribeirinhos, are among the people affected by the sickness.

The term ribeirinho is used to characterize people who live near to or on the margins of the rivers, igarapés (small rivers), lakes, and streams of the Brazilian Amazon Basin. In the literature, ribeirinhos are also named caboclos to account for European colonization and the consequent miscegenation among Indians, Portuguese settlers, and African slaves who migrated to the Brazilian Amazon during the rubber boom (the extraction of latex to meet international demand) (Harris 2006; Minzenberg and Wallace 2014); camponeses (peasants) to refer to their farming activities (Fraxe 2000); guardiões da floresta (forest keepers) to emphasize their cautious use of forest resources (Scherer 2004); amphibian men (Fraxe 2000); and water people (Furtado et al. 1993) to describe their intimate relationship with water and land during the periods that rivers overflow or recede. Accounted for in the Brazilian government census as rural population and scarcely represented in scientific studies (Silva 2006), ribeirinhos or caboclos are defined by Nugent (1993) as an invisible population. The Joshua Project estimates that 7041000 ribeirinhos live in the Brazilian Amazon (Joshua Project 2016).

Within the medical anthropology literature, three terms distinguish different conceptual systems related to disease, illness, and sickness. Despite the fact that these terms are colloquially used interchangeably, they refer to distinct ontological realities. Eisenberg (1977, p. 11), for instance, noted that "patients suffer 'illnesses'; physicians diagnose and treat 'diseases'.... [I]llnesses are experiences of disvalued changes in states of being and in social function; diseases, ... are abnormalities in the structure and function of body organs and systems". Eisenberg draws on the concept of disease to highlight body pathologies that a person is affected by, whereas he refers to illness to underline individuals' psychosocial experiences because of the disease. Young (1982) observed that despite concepts of disease and illness taking the individual as their point of reference to provide explanatory models, both concepts fall short because they desocialize the sufferer's experiences. Attending to this conceptual flaw, Young (1982, p. 270) referred to sickness as a "process of socializing disease and illness". By nuancing these concepts, I clarify that in this paper, I am interested in all three aspects of malaria intertwined, namely as a disease entity that is experienced bodily (illness) and lived socially (sickness). Furthermore, the disease entity is a socially constructed category pertaining to biomedical thought; a category that is lived and felt in multiple ways.

In what follows, I focus on ribeirinhos' experiential knowledge of malaria in the Brazilian Amazon. In this study, experiential knowledge is understood to be a form of knowledge that is built upon individuals' own experiences of health, sickness, and well-being. Experiential knowledge, scholars argue, includes the embodiment of biomedical knowledge to which people have access through health education campaigns and conversations with health professionals, among other media (Caron-Flinterman et al. 2005). That being said, in this paper, I ask how ribeirinhos experience and deal with malaria outside of a clinical setting. My intent is to show the local strategies used by ribeirinhos to discern malaria from the other febrile sicknesses they commonly experience, as well as shed light on the dynamics that emerge when someone falls sick. Although I describe local experiences of malaria, I do not compare them against scientific knowledge of this disease; rather my argument offers an illustration of multiple ways of knowing about and intervening in malaria beyond a clinical setting.

In Brazil, malaria services rely on two main diagnostic methods for detecting malaria in humans: microscopic diagnosis using stained thick blood smears, and rapid diagnosis tests (Brasil 2009). Particularly in the State of Amazonas, health education campaigns highlight that access to diagnosis and treatment is the main care approach to "fight" malaria in the "human host". Efforts to eliminate malaria in Brazil require close attention to ways afflicted people deal with 
malaria in their dwellings and communities. Populations have, after all, always played an active role in public health interventions aimed to control malaria. The reduction of $76.8 \%$ of malaria incidence in Brazil between 2000 and 2014 (PAHO 2016), for instance, was likely achieved with the participation of the local population. Recently, the World Health Organization (WHO) acknowledged that the success of malaria programs also depends on the participation of individuals living in malarious regions (WHO 2015). This study elucidates the particular ways in which malaria and its public health interventions intersect with the lives of the Amazonian populations from Brazil.

\section{Methods}

\section{Study design and settings}

This study draws on ethnographic design. According to Ellis (2004, p. 28), ethnography "means writing about or describing people and culture, using firsthand observation and participation in a setting or situation". Overall, ethnographic studies allow "a real historical agency to the people who figure in them" (Ingold 2014, p. 385). With that in mind, my ethnographic study was conducted between January and April 2015, in two locations: a peri-urban area of Manaus called the Brasileirinho community and a rural area of the Careiro municipality called the Panelão community. Both communities are malaria endemic areas and have been targeted by malaria interventions over the years. Each study community has a school that offers elementary schooling for children and adults. At the time of fieldwork, only the community of Brasileirinho had one malaria facility to offer diagnosis and treatment for malaria. In the Panelão community, diagnosis and treatment for malaria were offered to ribeirinhos through endemic disease control agents (EDCAs), who routinely visit homes to check if anyone needs to be tested for malaria.

\section{Population and sampling}

I used snowball sampling (Ritchie et al. 2006) as recruitment strategy. Ribeirinhos and EDCAs referred potential research participants to me. A total of 30 ribeirinhos were followed on a regular basis and interviewed. Research participants were selected in accordance with the following criteria: at least 18 years old, lived in one of the two study communities for at least 1 year, has had malaria at least once in the last 2 years, and agreed to participate in the research activities. Twenty-one women and nine men participated in the study (see Table 1). They ranged in age from 18 to 91 years. The high number of female participants in the research study may be reflective of fieldwork activities occurring during the day, when there were more women at home than men.

Of the 30 ribeirinhos interviewed, three were in treatment for malaria at the time of the interview, thirteen reported that they themselves and at least one family member who resides in the same house had suffered from one malarial bout in 2014, ten reported two to three family members that were sick from malaria in 2014, three stated that four to five family members had malaria in 2014 , and four noted that their family members had not succumbed to malaria in that year. Ribeirinhos communicate with health workers in a variety of ways including cell phones, oral messages asking other people to let health workers know that someone is sick, and putting a red cloth flag in front of their dwelling to show that someone in that home may be sick from malaria (see Fig. 1).

\section{Data collection}

I drew on participant observations (Ingold 2014) reporting how EDCAs perform malaria diagnosis in patients' homes, and conversations and interviews with ribeirinhos. I also used photographs (Pink 2014) to record how malaria appears in the ribeirinhos' communities. The interviews (Minayo 2007) were performed in Portuguese and were tape-recorded. As I participated in the 
Table 1. Socio-demographic characteristics of the research participants followed on a regular basis.

\begin{tabular}{|lcc|}
\hline Occupation & Men $(n)$ & Women $(n)$ \\
\hline Civil servant & - & 2 \\
\hline Elderly (retired) & 2 & - \\
\hline Farm caretaker & 3 & 1 \\
\hline House worker & - & 7 \\
\hline Industrial worker & 2 & - \\
\hline Peasant & 1 & 9 \\
\hline Police officer & 1 & - \\
\hline Seamstress & - & 1 \\
\hline Handcraft woman & - & 1 \\
\hline Total & 9 & 21 \\
\hline
\end{tabular}

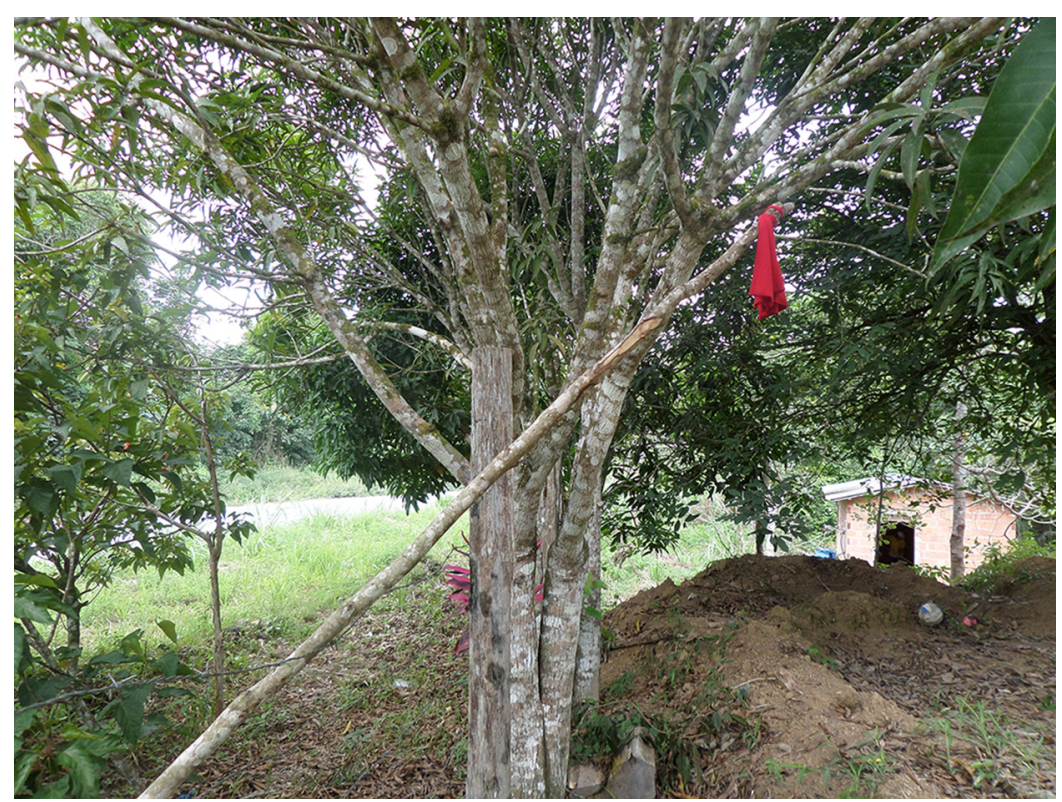

Fig. 1. Red flag as an indicator that a person is sick from malaria in a dwelling.

ribeirinhos' daily lives, my observations included their interactions with EDCAs, my own interactions with people dealing with malaria, and settings I have visited. Observations were recorded as field notes. Participant observations provided insight into how malaria is experienced from the perspective of individuals who deal with malaria as patients.

\section{Data analysis}

I used data triangulation (Denzin 2009) to analyze the ribeirinhos' experiences of malaria and to attain data saturation. Secondary sources of information such as biomedical textbooks, transcripts of interviews, and field notes were triangulated in this paper. Thematic analysis (Braun and Clarke 2006) was 
the method that I used to analyze data from interviews and field notes. In this study, themes were first identified inductively and then deductively. Ribeirinhos' experiences of malaria were organized into themes presented in the next section. The names of all research participants were changed to preserve their anonymity. Data analysis was performed without software.

\section{Ethical considerations}

The study was approved by the Research Ethics Board of the University of Ottawa, Canada (H10-14-10), and by the Ethics Review Committee of the Fundação de Medicina Tropical Doutor Heitor Vieira Dourado, Manaus, State of Amazonas, Brazil (CAAE: 37864014.9.0000.0005). Before being involved in the research activities, all interviewees were informed of the research goals, possible outcomes, confidentiality, their rights to withdraw their participation to the research at any time, and intended use of shared experiences in scientific publications and conferences. Written consent forms were signed by the research participants, granting authorization for the use of their images and statements for the purposes of this study and the dissemination of its results to the researcher.

\section{Results}

\section{Symptomatology and common ways malaria is experienced in the body}

Ribeirinhos who live in the Brasileirinho and Panelão communities were unanimous in saying that malaria is the most common sickness afflicting them. Malaria is defined by the ribeirinhos as a sickness that impairs one's liver and consumes one's blood. Ana Maria noted that "the pathways by which the blood disappears due to malaria are unclear since the only occasion I saw blood coming out of my body was when my finger was pricked to do the malaria diagnosis" (Ana Maria, Brasileirinho community). On many occasions, ribeirinhos mentioned that when someone is affected by malaria their eyes and skin become yellowish, their lips turn purple, their mouths develop a bitter taste, and the person suffers from chills despite the warmth of the Brazilian Amazon. Otávio described how the first symptoms of malaria unfold:

When I have malaria I feel severe headaches, cold, fever... I feel impatient... I want to eat, but a bitter taste spreads through my mouth even before taking the malaria pills. Then when I take the pills, I have nausea and vomiting... but how can a person who has eaten nothing vomit? Having malaria is an agony... I felt my body asking for something and I could not help myself. (Otávio, Brasileirinho community)

The majority of ribeirinhos reported that malarial infections debilitate a person physically and emotionally in such a way that their vitality disappears. The main implications of malaria indicated by my research participants are that this sickness weakens the blood and liver. They inferred that malaria causes anemia because they usually experience weakness and paleness during and after having malaria. Research participants also mentioned that they feel that malaria causes inflammation in the liver and that it may incubate in this organ for months or years after a malarial bout. José Mauro explained how malaria affects the liver:

Malaria attacks the liver. It takes off the immunity of liver. I don't know what happens inside me when I have malaria, but something changes. Sometimes I have the feeling that I partially recovered from malaria... I mean after I had malaria I could not eat the food I like, even salt, oil, sugar... all these things made me fell unwell. I also know that malaria can come back again or it can cause hepatitis too. My granddaughter is sick. The doctor said she has hepatitis and that she got it from water. I'm puzzled with this! I mean the water we drink here is good; it is from 
Table 2. Examples of comidas reimosas mentioned by ribeirinhos.

\begin{tabular}{ll}
$\begin{array}{l}\text { Food/beverages } \\
\text { Fish }\end{array}$ & $\begin{array}{c}\text { Example } \\
\text { Cephalus), curimatã (Prochilodus lineatus), and piranha, among others } \\
\text { Shrimp and crab }\end{array}$ \\
\hline Seafood & Armadillo, capybara, and peccaries \\
Game & All pork species and products made of pork \\
\hline Swine & Coffee, cupuassu (Theobroma grandiflorum), and bacaba vine (Oenocarpus bacaba) \\
\hline Beverages & Pupunha (Bactris gasipaes), cupuassu, bacaba, and watermelon \\
\hline Fruits & Amazonian manatee, eggs, tucupi (kind of sauce made of a wild manioc), and chelonians \\
\hline Others &
\end{tabular}

a 40-meter deep well. To be honest I think my granddaughter developed hepatitis because she had malaria many times and her liver lost its immunity. (José Mauro, Brasileirinho community).

The majority of my research participants indicated that malaria can return even if the person completes the appropriate treatment. To minimize the risk of malaria returning, ribeirinhos avoid eating comidas reimosas (see Table 2). Ribeirinhos defined comidas reimosas as foods and beverages with properties that are thought to trigger inflammatory processes. Milagres elaborated on the relationship between malaria and comidas reimosas:

A person who has malaria cannot eat fried eggs, or eat beans and eggs. She needs to eat something light... soup ... fish ... but sometimes it is difficult to eat light food because a person who has malaria gets debilitated, loses her vitality... so she cannot work and if she does not work, she will not have money to buy food that is not reimosa. This is not a question of choice... if a person eats these comidas erradas [wrong food or comida reimosa], malaria will come back again because malaria medications clean the blood but malaria stays in the liver. If you don't eat comidas reimosas for a period after having had malaria, you will recover from it, but if you eat them during the time you are not good yet, malaria will return. (Milagres, Brasileirinho community)

Chico explained the reaction of doctors when he mentioned that comidas reimosas cause sicknesses:

Doctors say this [comidas reimosas] is a foolish thing... that there is nonsense in saying that comidas reimosas can provoke sicknesses. I argue with them! I know by myself that comida reimosas worsen malaria in the body. (Chico, Panelão community)

The stories told by Milagres and Chico attest to the multiple ways people experience and understand the occurrence of malaria.

\section{Nosology: classification of malaria according to experiential knowledge}

In the stories, ribeirinhos told me about their experiences with malaria; scientific names such as vivax (Plasmodium vivax) and falciparum (P. falciparum) malaria were rarely mentioned. Instead, ribeirinhos indicated that the most common types of malaria afflicting them were mild malaria, strong malaria, and both at once. These three forms of malaria are experienced with a similar symptomatology; the differences lie in the severity of symptoms. In fact, ribeirinhos reported that individuals affected by strong malaria sometimes yell due to severe headaches, and that they are affected by dizziness, blurred vision, and, in some cases, loss of consciousness. In contrast, in the case of mild malaria, 
a person experiences pain and dizziness, but they rarely pass out. Marcos shared his experience with strong malaria:

It was a malaria I was not prepared for... its symptoms were so strong that I passed out, I was very bad... I had terrible headaches, cold... I felt weak and could not walk without the help of my wife... Even though I had not eaten anything I threw up a lot... I threw up a green thing [bile] ... it was horrible. (Marcos, Brasileirinho community)

Most ribeirinhos reported that strong malaria now rarely appears in their communities. Within these communities, memories of past outbreaks of strong malaria were narrated through a metaphor that weaves together stories of people and animals that were affected by the sickness. Luzinete explained:

Some years ago, malaria was merciless of us. It affected everybody, my family, myself, my neighbours, and my pigs and chickens. I saw the poor animals shivering because of strong malaria. (Luzinete, Panelão community)

The third type of malaria mentioned by the research participants occurs when a person develops both the mild and strong forms of malaria at once, or comes down with a different type of the sickness directly after finishing the treatment for a previous malarial bout. Indications that a person may have another type of malaria are that the malarial malaise does not clear up when they are taking antimalarial medications for either vivax or falciparum malaria, or when the malaise persists after the pharmaceutical treatment ends. Marina explained how a person knows if two types of malaria afflict them at once:

I was taking the pills but I continued to shiver... I shivered all the time. So my grandmother asked the EDCA to prick my finger again. He did it. Few hours later he came back and told me I had another malaria. He said it was not the same malaria I was taking the piulas [pills]; rather, it was another and I had to take other kind of medication besides the medicines I was already taking. (Marina, Panelão community)

Another way that ribeirinhos have developed to discern the types of malaria affecting them is to observe the kinds of medications provided to them by malaria services upon microscopic confirmation of the disease. However, ribeirinhos do not mention the names of the medications used, including chloroquine and primaquine for treating vivax malaria and coartem or lumeter for treating falciparum malaria. Rather, they explained that they were often treated with medications dispensed in five to seven separate small paper bags. They treated themselves with one bag of pills once a day. Yet, some ribeirinhos reported that they sporadically received pills packaged in cartelonas [large plastic blisters], to be taken in the mornings and evenings. Dalva explained how she perceived that different types of malaria affected her:

The first time I had malaria I received the piulas [pills] in cartelonas [large plastic blisters] and I took them in mornings and evenings for three days, I think. Those piulas [lumeter or coartem pills] were different from the ones I received when I had the second malaria. In the second time the piulas came in seven small paper bags. During seven days, I took them once a day. In the first days of the treatment there were a lot of piulas inside the paper bags, I mean the big ones [chloroquine] and the small ones [primaquine]. Near to the end of the treatment there were only two small pills to take. (Dalva, Panelão Community)

Ribeirinhos' experiences of malaria show that in their homes and communities, biomedical categories commonly used to link malarial infections to the infective parasite are not used. Rather, the nuances of the types of malaria relate to the intensity of symptoms, the interval between infections, and medications taken. 


\section{Etiology: encounters between humans and malaria vectors}

Within the study communities, the understanding of how malaria is transmitted to people varied substantially. Irma, Lauro, Patrícia, and Carlos explained their views of how a person may come down with malaria:

The EDCA told me that we get malaria from carapanãs [mosquitoes], and I believe that is true. But I also think we can get malaria from the sun. I say this because once my daughter was playing in the hot sun and I think within an hour or so, she came back home and passed out. At that time, there was a malaria facility here in our community and I took my daughter there. Later on the EDCA brought medicines because she had malaria. She fainted in the afternoon and at that time there were no mosquitoes out there. It was the sun that made her sick from malaria. (Irma, Panelão community)

I cannot say exactly from where I can catch malaria because it is a sickness nobody knows from where it comes. I speak from myself... I did not see what makes me sick from malaria... because malaria is a kind of sickness that when a person realizes something is not good with her... it is malaria. So... I think malaria comes in the wind... that there is something in wind that makes me sick from malaria. Sometimes, I think I can get malaria from water because I bathe in a river... perhaps there is a microbe in the water and when I bathe in it, microbes enter my body. (Lauro, Brasileirinho community)

I had malaria once and I caught it in my mothers' house. She was recovering from malaria and I drank a glass of water that was not clean... I mean there was malaria in the glass. Soon after I drank the water in that glass I began to feel unwell ... with headaches. Few days later I did the malaria test and it was positive. (Patrícia, Panelão community)

In the morning I went to my backyard to gather buriti fruits [tropical fruit from the Mauritia flexuosa tree]. When I came back from there I began to feel a strong headache and chills. Since then, I got worse. I put a red cloth in front my house, so the EDCA would know I was sick from malaria. He came over and pricked my finger. In the afternoon he brought me the remédios [medicines]. I think malaria was there in the buriti trees when I was gathering the fruits. (Carlos, Brasileirinho community)

The pathways by which malaria gets inside a person's body, which were indicated by Irma, Lauro, Patrícia, and Carlos, go beyond the biomedical characterization of malaria transmission and include the sun, wind, water, and people who were previously affected. In some cases, malaria is seen as an entity that enters the body by itself. Patrícia and Carlos' views also demonstrate that they feel that malaria happened instantly when they came into contact with the potential malarial agent. In addition to mentioning a number of agents involved in malaria transmission, ribeirinhos highlighted that malaria occurs in specific settings; that is, riverine people are more likely to develop the sickness. This is why they perceived that they themselves are affected by malaria more frequently than individuals who live away from the forest areas and rivers, like in the city. Haroldo elaborated on the relationship between malaria and places:

The EDCA told me that the malaria carapana [mosquito] lives near to rivers and forests. If what he said is really true, here there is malaria everywhere because there are trees and rivers in all places. Of course it depends on having a carapanã with the malaria virus. In this case, I agree with the EDCA because I had more than 30 malarias [malarial bouts] and I always lived and still live close to rivers. Thus, I believe that we ribeirinhos can catch malaria more frequently than other people who live in the city. (Haroldo, Brasileirinho community)

When malaria-carrying mosquitoes were implicated in the transmission of the disease, ribeirinhos indicated that these disease vectors usually attack people at specific times: from 1700 to 2000 and from 
0500 to 0600 . Although ribeirinhos reported times during which the risk of catching malaria increases, in practice, they challenged this information when it was was relayed to them by public health workers. Lidiane revealed her disagreement with this information.

Public health workers usually say that to prevent malaria we should avoid going to the forest and bathe in the rivers especially during the dawn and dusk. I think this is not true because here in my community there are a lot of children, youth, and seniors who came down with malaria and they don't go to fishing, swimming, or hunting in the forest. So, I think as we live in the forest, malaria can catch us anytime, regardless of the activities we engage in. (Lidiane, Panelão community)

Lidiane's risk perception of malaria as a sickness that may affect people at any time of the day highlights that in ribeirinhos' communities, biomedical knowledge is not easily incorporated into their everyday lives because it does not reflect the reality that riverine people experience.

\section{Health-care-seeking practices: the place of experience in discerning malarial bouts from other sicknesses at home}

In the conversations I had with ribeirinhos, I learned that they have developed multiple diagnosis strategies to distinguish malaria from other sicknesses that are endemic in the Brazilian Amazon such as dengue fever, chikungunya, and influenza (locally called virose). The classical symptoms of these sicknesses described by ribeirinhos are cold, fever, body pain, and headaches. My research participants argued that these symptoms overlap with those of malaria. Helena, Vanderléia, Paulo, and Haroldo explained their strategy for determining if the sickness that they are experiencing is malaria:

Usually, when the symptoms begin, I think it can be virose, but malaria has its own way. I mean its symptoms appear in a specific hour. So, I look at my watch and mark the time I feel bad. In the next day, if the symptoms appear at the same time again, I know it is malaria. In general, I wait 48 hours to ask the EDCA come to my home to prick my finger. (Helena, Brasileirinho Community)

When I have malaria I feel a lot of pain in my body. I feel like I am being pierced by thorns [tingling sensation]. I also feel cold and weakness like I was almost without blood in my body. So, I begin to self-monitor my symptoms for about three days. If these things [symptoms] persist I try to contact the EDCA. I have neither a phone to reach him nor money to go to the city. So, I ask the guy who drives people from here to the city to tell the EDCA that I need to be tested for malaria. (Vanderléia, Panelão Community)

When I want to know if I have malaria or virose I eat a roasted calabreza sausage; it is a kind of comida reimosa. After doing so, I feel very bad due to severe headaches, body pain, stomach discomfort... this happens because this food brings malaria out of my body. In the case of virose, I can eat many roasted calabreza sausages and I feel good. Actually, comida reimosa worsens [symptoms of] malaria but has no effect on virose. (Paulo, Brasileirinho community)

I work as a steam boiler operator and if I am cold near to the boiler, I know this is a symptom of malaria. I do not fail in distinguishing between malaria and virose. Malaria is very different from flu or other sicknesses. Having fever is similar, but malarial fever, that is, the cold caused by malaria is a cold that is very different. It is like you are in Antarctica! Like you are freezing all over. It is rare I feel sick in a malarial way and the malaria test shows the contrary. (Haroldo, Brasileirinho Community)

Ribeirinhos who had experienced multiple malarial bouts were more likely to resort to empirical diagnosis practices before seeking biomedical diagnosis. In contrast, ribeirinhos who had no experience with malarial infections commonly associated malaise with a variety of previous experienced 
sicknesses, such as urinary tract infections, migraines, virose, or heart failure, among others. They were also prone to spending more days at home before seeking health care. Indeed, most of them waited long enough to experience intense pain, desperation, emotional distress, and fear of dying, as Luzia explained:

I had severe headaches that I could not open my eyes. I shivered a lot. I thought I was feeling those things [symptoms] due to a heart issue I have. For many days I cried a lot. I thought I would leave my kids here [thought was going to die]. Four days passed and I was more and more sick. So, my son came to visit me. When he met me he said "Mom, I think you have malaria". He took me to the hospital. There, I was told I had malaria. (Luzia, Panelão Community)

The occurrence of malaria also challenges health professionals when attempting to diagnose the disease, as fever, vomiting, headaches, and body pain are sometimes associated with conditions other than malaria. Rosilene shared her experience:

I was not feeling well for about three days. I had headaches, vomiting, and felt an intense cold. My husband took me to a hospital. I told the doctor I was pregnant. So, he required a urine test. After that I was told I had virose. One week later, I was more sick. My husband and my daughter fell sick too. A friend suggested we had malaria. We all got very sick... we threw up many times, had chills, headaches, and weakness... We didn't have money to pay for a taxi or bus, so a police officer drove us back to the hospital again. That time my husband asked a nurse for a malaria test. All of us had malaria. It took almost two weeks to know it. (Rosilene, Brasileirinho community)

Ribeirinhos' experiences of malaria attest to the key role of experiential knowledge in seeking early diagnosis. Furthermore, the stories told by Luzia and Rosilene demonstrate that even in a region where malaria is the prevalent sickness afflicting the population, for certain individuals-ribeirinhos or medical professionals-it can be misinterpreted as other febrile sicknesses/diseases.

\section{Misalignment of body and biomedical diagnosis of malaria: from technologies to (mis)information}

The main way to access antimalarial medications recommended by the Brazilian Malaria Prevention and Control Program (BMPCP) is to perform a malaria diagnosis test. However, the decision to be tested for malaria does not necessarily mean that it will be detected early. Many ribeirinhos indicated that on some occasions they were screened for malaria multiple times because the disease was not promptly identified in their blood. From the time that ribeirinhos experienced malarial symptoms until the confirmation of the disease through biomedical diagnosis, they struggled to maintain their day-to-day routines and responsibilities (working, studying, leisure activities, etc.). Giselda shared her agonizing journey until the biomedical confirmation of her malaria.

There has been about two years that I had my first malaria. I felt a malaise... strong headaches, and dizziness. I couldn't walk by myself, I needed someone to hold me otherwise I would fall on the floor. I asked my neighbour to tell the EDCA I was sick. The EDCA came to my place and did the malaria test, but the test was negative for malaria. I continued to feel sick... I shivered a lot and was numb. My boyfriend called the hospital in Careiro and an ambulance was sent to pick me up. In the hospital, I was tested for malaria and, again, it was not detected. The doctor said I had urinary tract infection. He prescribed medications and sent me home. Two days after, I got worse... and you know that here everything is difficult... access is difficult... money is not easy too. Anyway, I got a motorcycle-taxi to Careiro and from Careiro I took a bus to Manaus. It was a long journey because I was feeling 
depleted of my forces... [I was] very weak indeed, and the ferryboat was not fast. My sister was waiting for me in the Ceasa port in Manaus. From there we went to a hospital and, I finally learned I had malaria... vivax malaria the doctor said. I didn't stay in the hospital but I did the treatment in Manaus. (Giselda, Panelão Community)

Difficulties arising from current biomedical tools used to diagnose malaria were reported by many of my research participants. Marcos, for instance, attributed delays in detecting malaria to laboratory technicians' lack of skill in analyzing the glass slides and (or) the use of old equipment to perform the diagnosis.

I had my finger pricked four times but malaria was not detected. But I continued to weaken... I went to work and felt terribly bad. When I arrived at home I lay down on the sofa because I was tired, weak, and in pain. It took a day before I felt I needed to go a reference center for tropical diseases. I asked my son-in-law to drive me there because I was not able to drive myself. There I finally learned I had malaria. I do not know why there they [health professionals] found malaria in my blood so quickly. I think there health professionals are more prepared to examine our blood or the [diagnostic] equipment is better than those of the malaria facility close to my home. (Marcos, Brasileirinho community)

In a conversation with another ribeirinho, she also told me that on some occasions she had her finger pricked more than two times before malaria was identified by the biomedical test. She asked an EDCA why the disease was not detected in her blood sooner.

The EDCA pricked my finger three times or so and said that I didn't have malaria. The problem was that I continued experiencing strong headaches. I took dypirone [a brand of pain killer used in Brazil] but the pain didn't reduce. I was sure I had malaria. So I asked him why this happened... I mean... why I felt I had malaria but the test was negative. He said that some medications used to relieve fever or headaches influence the results of the malaria test. That is, malaria does not appear in the blood if a person takes strong medications. (Cleide, Brasileirinho Community)

Many of my research participants followed EDCAs' recommendations of avoiding fever reducers and painkillers prior to performing biomedical diagnosis. Overall, Giselda, Marcos, and Cleide's experiences illustrated the suffering they endured until the disease was diagnosed, as well as their arduous journeys when they sought malaria care outside of their communities.

\section{Malarial infections and the becomings of bodies and experiences}

The majority of the research participants stated that malarial bouts cause physiological and existential changes in them. Thus, some of them reported that their bodies changed and are still changing after they being afflicted by malaria. Weakness, fatigue, intolerance to fatty foods and comidas reimosas, and occurrences of side effects of the antimalarial medications are some examples of physiological changes indicated by the research participants. Ribeirinhos also mentioned that after the third malarial bout they became able to recognize and deal with pain and discomfort caused by the illness. Felipa said:

The person who already had three malarial bouts knows very well the illness symptoms. I know that when I feel headaches and chills, these are symptoms of malaria, so I call the EDCA. He performs the test and it shows I am positive for malaria. I learned by myself, I mean, malaria taught me its symptoms. (Felipa, Panelão community)

Research participants also mentioned that their previous experiences of malarial infections prepared them for perceiving if a relative or friend is sick from malaria, because a person who is 
affected by malaria looks tired, pale, sad, and sometimes she becomes aggressive due the difficulties of bearing pain. Carlos explained how he identifies malaria in himself and in other individuals as well:

In the first days a person is being afflicted by malaria she begins to lose a bit of blood in her face; she becomes pale. I can perceive changes in the hollowing of her cheeks... paleness is on the person's face... these are symptoms of malaria. Further, severe headaches, body pain and discomfort caused by intense vomiting, cold, and shivering turn an energetic individual into a languid person, a calm subject into an aggressive one, and a dynamic person into a temporarily disabled individual. (Carlos, Brasileirinho community)

I asked Felipa and Carlos about the main implications of becoming able to identify their own possible malarial bouts as well as those of others. They explained that by having had many malarial bouts, their role in the community changes. That is, they can both help others to understand what is it to be sick from malaria and share practices of how to deal with it such as recommending traditional treatments to help them recover from the sickness.

\section{Vicissitudes of having malaria}

Among ribeirinhos, their first malarial bouts are seen as a rite of passage for individuals who wish or are pushed to live in the peri-urban or rural areas of the Brazilian Amazon. Luzia and Marlene described how they decided to move to rural and peri-urban communities:

Before living here in the Panelão community we lived at Careiro in a precarious shack on a riverbank. Every time the river overflowed it took part of our dwelling along. The shack was close to falling apart. So, we were given a land lot here in the Panelão community. We built another shack and began our own vegetable garden. We planted manioc, banana, cupuassu [a tropical fruit scientifically called Theobroma grandiflorum]. Now we have food to sustain ourselves and to sell. We had health issues in the city but malaria was not a problem there. It is sad to see my children sick from malaria and I also suffered due to malaria, but we are doing better here than in the city. We will stay here! (Luzia, Panelão Community)

My family and I used to live in Itacoatiara. At that time, it was very difficult for us to feed and clothe our four children because there were no jobs in that city. So, we decided to move to Manaus. We thought that in Manaus there were more jobs for electricians and bricklayers. We came to Manaus and stayed in a relative's home. My husband quickly found a job. Three years ago [2012] we learned that a doctor was looking for a property caretaker. We moved to here and since then we have had some struggles with malaria. Last year [2014], my husband, my infant son, and I had malaria. There is that river behind the house. I think we got malaria from there. (Marlene, Brasileirinho community)

Irma used the term novato [newcomer] to call my attention to stories of people like Luzia and Marlene who moved into their communities and experienced health issues due to their first encounters with malaria. Irma explained that malaria seems to have a preference for novatos:

Ah! malaria loves the novatos! I remember a young woman who moved from Manacapuru to here. She was a beautiful woman and malaria stuck on her [she laughs]. Every time she got sick from malaria the EDCA brought her pills but she got sick over and over. When she got better her grandson caught malaria too. She was treated for malaria several times and in one occasion the medications made her urinate blood. She got scared from malaria and moved out. Since then, I never heard from her anymore. (Irma, Panelão community) 
The story told by Irma demonstrates that malaria constitutes a serious health issue to individuals who have no previous experience with the sickness. In contrast, ribeirinhos, who are used to malaria, do not perceive it as a threat to their lives. In fact, they indicated that AIDS and cancer are more serious sicknesses than malaria because people can die from these maladies. Moreover, my research participants observed that they know how to deal with malaria, and free medicines are dispensed to sickened individuals and delivered to their homes. Patrícia shared her experience with malaria:

It is difficult to deal with malaria because it is an illness that provokes body pain and malaise all the time. But it is not a bicho de sete cabecas [big deal]. If a person takes the medications accordingly, eventually it goes away, soon or latter it will come back again. This is our reality here. (Patrícia, Panelão community)

I also discussed with my research participants the risks of catching malaria relative to other issues they usually face in their communities. José Mauro explained:

For me malaria is not a major problem here. There are worse issues in our community. Look at the roads... when it rains it becomes extremely dangerous to drive in these roads and there is not bus to attend people who live in the ramals (inner areas of the Amazon forest). Some days ago, a guy called me at night because he needed my help to drive him to a hospital. Unfortunately, I couldn't help him because it was raining and the road was too slippery. This applies to malaria too... I mean if someone happens to come down from malaria in a rainy day the EDCA will not reach him... so the guy will have to deal with malaria by himself until the weather clears and road conditions improve. (José Mauro, Brasileirinho community)

Overall, research participants pointed out that malaria is a difficult experience for them as it causes turmoil in their lives, but it is a sickness one can learn to deal with.

\section{Discussion}

The purpose of this study was to describe ribeirinhos' experiences, understanding, health care practices, and vicissitudes of having malaria in the Brazilian Amazon. The findings of the study show that the symptomatology of malaria reported by ribeirinhos such as headaches, cold, chills, weakness, anemia, and vomiting, is described in studies presenting the clinical characterization of the disease (Breman 2001; Warrel and Giles 2002; Anstey et al. 2009). Despite the fact that ribeirinhos associated these symptoms with malaria, they often defined the malarial body in relation to blood and liver abnormalities; altered sensorial experiences such as paleness, cold, and changes in taste; and emotional distress resulting in aggressive attitudes triggered by the inability to bear pain, vulnerability, and loss of vitality.

Instead of using biomedical terms, namely vivax malaria, falciparum malaria, and mixed malaria, ribeirinhos developed their own standards to characterize the malarial bouts they experience. Such standards take into consideration the intensity of symptoms (mild and strong malaria), the interval between infections (two types of malaria at once), and the types of antimalarial medications dispensed by health services. Ribeirinhos also present a peculiarity of views regarding malaria transmission. That is, although ribeirinhos acknowledged that a mosquito vector transmits malaria, they also indicated other means through which malaria can get inside their bodies such as sun exposure, wind, microbes, person-to-person transmission, and malaria itself as a pathological agent.

This study reveals discrepancies between the notion of risk informed by public health workers and ribeirinhos' experiences of malaria. From ribeirinhos' perspective, malaria can catch them everywhere, whereas from the public health workers' view, the disease risk increases with activities that bring people to malarious areas. Information passed on to ribeirinhos is decontextualized in that it 
serves more to inform people who visit forest areas of the Brazilian Amazon than those who live in malarious risk areas and are more vulnerable to the sickness. This finding is important as it can provide guidance to public health professionals for designing context-driven educative messages that reflect the local conditions associated with malaria transmission.

This study found that the consumption of comidas reimosas is used as an empirical diagnosis strategy and (or) as a treatment approach to prevent malaria from worsening or recurring. Comidas reimosas are defined as types of foods that are regularly consumed by individuals, which become harmful to them due to health issues including malaria (Currier 1966; Baião et al. 2013). The practice of abstaining from eating comidas reimosas during a sickness can be understood as a form of Hippocratic-Galenic medieval medicine, which was brought to Latin America through Spanish and Portuguese settlers (Foster 1987). This ancient medical practice is based upon the principle of opposites such as hot/cold or humoral pathology; its principles are widely disseminated in the country, particularly in the states of the Brazilian Amazon (Woortmann 2008). Murrieta (2001) observed that the reima is characterized by binary oppositions between harmful and non-harmful foods. However, in ribeirinhos' views, the temperature of comidas reimosas is not seen as detrimental to their health. Rather, they contrasted strong nutritional characteristics of these foods against a weak/fragile individual's body.

Ribeirinhos were consistent in saying that malaria is the prevalent sickness affecting them. They also stressed that malarial symptoms are similar to other febrile sicknesses occurring in the Brazilian Amazon. Therefore, ribeirinhos developed empirical diagnostic techniques to confirm if the malaise experienced is malaria. In this sense, ribeirinhos' attention to the specific hours a malaise occurs, the time length symptoms persist, the milieu in which the sickness manifests, and the influence of comidas reimosas on malarial symptoms constitute the multiple ways in which malaria is experienced/perceived outside of a clinical setting. The body, as the perceiver subject, plays a key role in the distinction of malaria from other sicknesses. Perception, as Merleau-Ponty conceptualizes it, is "a sort of life of significations that renders the concrete essence of the object [in this study the object is malaria] immediately readable and that allows its 'sensory properties' to appear through it" (2014, p. 133). As this study shows, individuals who had no previous experiences with malaria were not able to identify the sensorial properties of malaria; hence, they were found to spend more days at home before seeking health care assistance. This finding highlights the relevance of experiential knowledge in distinguishing malaria and in seeking biomedical diagnosis.

The empirical diagnosis strategies that this study reports are examples of ribeirinhos' embodied skills, which were likely built on their own experiences of malarial bouts and social interactions with other individuals who had also dealt with the sickness. From an anthropological perspective, the process of learning through lived experiences can be understood through the concept of enskillment, that is, "the embodiment of capacities of awareness and response by environmentally situated agents [individuals]" (Ingold 2000, p. 5). Besides, as Csordas (2002, p. 2) argued, understanding events (a sickness for instance) through an embodiment lens "leads not to the irreducible objective reality of a biological body, nor to the indeterminacy of endlessly iterated subjectivity, but to a necessarily indeterminate reality". Acknowledging the existence of these multiple realities is the first step towards the decolonization of people's knowledge about sicknesses. As Farley (2003) reminded us, in his historical account of bilharzia and imperial tropical medicine in British and American empires, since the advent of the enlightened medicine, people's practices of sicknesses were deemed useless, harmful, and meaning nescience or rejection of scientific achievements. By describing people's empirical practices of diagnosing malaria, I do not characterize them as inappropriate or non-modern. On the contrary, I understand that these practices attest to the creative entanglements between popular and biomedical knowledge and between biological and social domains. 
This study also documents research participants' perception of the low effectiveness of biomedical diagnosis because of the multiple times that they had to repeat the blood smear test. Although the biomedical literature reports the difficulty in identifying malaria parasites using current diagnostic methods (Ferreira and Castro 2016), studies have often overlooked people's struggles with such diagnostic technologies. This study, in contrast, described the ups and downs of individuals who agonized until the disease was confirmed. People having to repeat the biomedical diagnosis of malaria multiple times is evidence that "disease is never just one thing, technology delivery does not translate into patient care, and biology and technology interact in ways we cannot ways predict" (Biehl and Petryna 2013, p. 4).

Accordingly, ribeirinhos indicated that EDCAs frequently recommended that they avoid taking painkillers and fever reducers $1 \mathrm{~d}$ before they seek biomedical diagnosis. This recommendation is not, however, supported by clinical evidence and is not addressed in guidelines informing diagnosis procedures (Brasil 2002, 2006). Such a recommendation illustrates gaps in translating biomedical knowledge into quality information for patients. That is, although the majority of EDCAs are trained to collect blood and fill out disease notification forms, they are minimally prepared to answer questions regarding the clinical manifestation of malaria asked by their patients. I shed light on issues of knowledge translation (Straus et al. 2009) to call attention to inadequacies in the training of the primary professionals in charge of providing health care to patients with malaria, as well as the patient's rights of access to quality health information. In particular, this finding can provide context for the content of training offered to EDCAs as it attests to the need of disseminating reliable information on malaria and its clinical manifestations.

This ethnographic study also sheds lights on work, housing, food, and clothing insecurities that motivated people move to rural and peri-urban communities where malaria is endemic. Ribeirinhos' stories of encounters with malaria highlight the lack of government policies addressing socio-economic insecurities that expose people to malaria pathogens and its disease vectors. Overall, the findings of this study provide us with a sense of the social dynamics that are tightly entangled with malaria occurrence in the Brazilian Amazon.

\section{Conclusion}

My goal was to provide insight into the experiential knowledge of malaria circulating in riverine communities, the interactions between individuals afflicted by this sickness and health care services offering malaria diagnosis, and the vicissitudes of having malaria in the State of Amazonas, Brazil. This paper characterized the genuine ways that ribeirinhos developed to distinguish malaria from other febrile sicknesses occurring in the Brazilian Amazon, and how such empirical strategies work in coordination with biomedical diagnosis. This study described gaps in the training of EDCAs. Hence, it is important to improve the quality of training offered to these health professionals.

I described issues related to the accuracy of malaria diagnosis methods and how these issues affected individuals presenting malaria symptoms. Biomedical diagnosis is the "access door" to free medications for treating malaria in Brazil. Failures in the prompt detection of this disease raise questions about the quality of malaria services offered to ribeirinhos, and the sole focus of the BMPCP on containing the disease rather than also addressing root causes of malaria. In this paper, I also highlighted individuals' life journeys that led them into malarious areas. A close examination of these paths revealed the "naturalization" of malaria transmission among people who live in the peri-urban and rural areas in which I conducted this ethnographic study. The fact that ribeirinhos are likely to experience malaria as part of their lives calls attention to public health discourse that depicts malaria as a typical disease of the Amazon region, rather than a result of fragile and entangled social, political, economic, ecological, and biological factors. 


\section{Acknowledgements}

This study is part of the research project "Ribeirinhos' experiences and practices of malaria in the Brazilian Amazon", which received support from the Globalink research grant (IT04521) funded by MITACS and a research travel grant provided by the Faculty of Graduate and Postdoctoral Studies from the University of Ottawa. I am grateful for their financial support. I also extend my grateful thanks to Dr. Julie Laplante, who reviewed this manuscript, health workers from Manaus and Careiro, State of Amazonas, Brazil, and the research participants for their time and generosity while participating in this study.

\section{Author contributions}

Conceived and designed the study: LMFS. Performed the experiments/collected the data: LMFS. Analyzed and interpreted the data: LMFS. Contributed resources: LMFS. Drafted or revised the manuscript: LMFS.

\section{Competing interests}

The author has declared that no competing interests exist.

\section{Data accessibility statement}

All relevant data are within the paper.

\section{References}

Anstey NM, Russell B, Yeo TW, and Price RN. 2009. The pathophysiology of vivax malaria. Trends in Parasitology, 25(5): 220-227. doi:10.1016/j.pt.2009.02.003.

Baião MR, de Souza Santos MMA, Líbera BD, and Machado RCM. 2013. Puerperium and its socio cultural dimension from the perspective of women living in Manguinhos-Rio de Janeiro, RJ, Brazil. DEMETRA: Alimentação, Nutrição \& Saúde, 8(Suppl. 1): 309-320. doi:10.12957/ demetra.2013.6562.

Benchimol JL, and da Silva AFC. 2008. Railroads, disease, and tropical medicine in Brazil under the first Republic. História, Ciências, Saúde-Manguinhos, 15(3): 719-762.

Biehl J, and Petryna A. 2013. Critical global health. In When people come first: critical studies in global health. Edited by J Biehl and A Petryna. Princeton University Press, New York, New York. pp. 1-20.

Brasil. 2002. Ações de controle de endemias: malária: manual para agentes comunitários de saúde e agentes de controle de endemias. (Ministério da Saúde, Ed.). Ministério da Saúde, Brasilia, DF.

Brasil. 2003. Programa nacional de prevenção e controle da malária. (Ministério da Saúde, Ed.). Ministério da Saúde, Brasília, DF.

Brasil. 2006. Ações de controle da malária: manual para profissionais da saúde da atenção basica. Ministério da Saúde, Brasília, DF.

Brasil. 2009. Manual de diagnóstico laboratorial da malária. 2nd edition. Ministerio da Saude, Brasilia, DF.

Braun V, and Clarke V. 2006. Using thematic analysis in psychology. Qualitative Research in Psychology, 3(2): 77-101. doi:10.1191/1478088706qp063oa. 
Breman JG. 2001. The ears of the hippopotamus: manifestations, determinants, and estimates of the malaria burden. American Journal of Tropical Medicine and Hygiene, 64(1-2 Suppl.): 1-11.

Camargo EP. 2003. Malária, maleita, paludismo. Ciência E Cultura, 55(1): 26-29.

Caron-Flinterman JF, Broerse JEW, and Bunders JFG. 2005. The experiential knowledge of patients: a new resource for biomedical research? Social Science \& Medicine, 60(11): 2575-2584. doi:10.1016/j. socscimed.2004.11.023.

Csordas TJ. 2002. Embodiment as a paradigm. In Body/meaning/healing. Palgrave Macmillan, New York, New York. pp. 58-87.

Currier RL. 1966. The hot-cold syndrome and symbolic balance in Mexican and Spanish-American folk medicine. Ethnology, 5(3): 251. doi:10.2307/3772771.

Denzin NK. 2009. The research act: a theoretical introduction to sociological methods. Aldine Transaction, New York, New York.

Eisenberg L. 1977. Disease and illness: distinctions between professional and popular ideas of sickness. Culture, Medicine, and Psychiatry, 1(1): 9-23. doi:10.1007/BF00114808.

Ellis C. 2004. Class two: the call for autoethnography stories. In The ethnographic I: a methodological novel about autoethnography. Altamira Press, Walnut Creek, California.

Farley J. 2003. Bilharzia: a history of imperial tropical medicine. Cambridge University Press, New York, New York.

Ferreira MU, and Castro MC. 2016. Challenges for malaria elimination in Brazil. Malaria Journal, 15(1): 284. doi:10.1186/s12936-016-1335-1.

Foster GM. 1987. On the origin of humoral medicine in Latin America. Medical Anthropology Quarterly, 1(4): 355-393. doi:10.1525/maq.1987.1.4.02a00020.

Fraxe TJP. 2000. Homens anfíbios: etnografia de um campesinato das águas. Annablume, Fortaleza, CE.

Fraxe TJP. 2004. Cultura cabocla-ribeirinha: mitos, lendas, e transculturalidade. Annablume, Sao Paulo, SP.

Furtado LG, Leitão W, and de Mello AF. 1993. Povos das aguas: realidade e perspectivas na Amazonia. Museu Paraense Emílio Goeldi, Belem, Para.

Governo do Estado do Amazonas. 2016. Dados sobre o estado do Amazonas. [online]: Available from amazonas.am.gov.br/o-amazonas/dados/.

Harris M. 2006. Presente ambivalente: uma maneira Amazonica de estar no tempo. In Sociedades Caboclas Amazônicas: Modernidade e Invisibilidade. Edited by C Adams, RSS Murrieta, and W Neves. Annablume, São Paulo, SP. pp. 81-108.

Hochman G. 2009. "O Brasil não é só doença”: o programa de saúde pública de Juscelino Kubitschek. História, Ciências, Saúde-Manguinhos, 16: 313-331. doi:10.1590/S010459702009000500015. 
IBGE. 2016. Estimativas da População Residente no Brasil e Unidades da Federação com Data de Referência em 10 de Julho de 2016 [online]: Available from ftp.ibge.gov.br/ Estimativas_de_Populacao/Estimativas_2016/estimativa_2016_TCU.pdf.

Ingold T. 2000. The perception of the environment: essays on livelihood, dwelling and skill. 2nd edition. Routledge, New York, New York.

Ingold T. 2014. That's enough about ethnography! Journal of Ethnographic Theory, 4(1): 383-395. doi:10.14318/hau4.1.021.

Joshua Project. 2016. Ribeirinhos: Amazon river peoples in Brazil [online]: Available from joshuaproject.net/people_groups/11073/BR.

Merleau-Ponty M. 2014. Phenomenology of perception. Translated by Donald Landes (English tr). Routledge, New York, New York.

Minayo MCS. 2007. Pesquisa social: teoria, método e criatividade. 25th edition. Vozes, Petrópolis, RJ.

Minzenberg E, and Wallace R. 2014. Amazonian agriculturalist bound by subsistence hunting. In Amazonian geographies: emerging identities and landscapes. Edited by JM Vadjunec and M Schmink. Routledge, New York, New York. pp. 73-98.

Murrieta RSS. 2001. Dialética do sabor: alimentação, ecologia e vida cotidiana em comunidades ribeirinhas da ilha de Ituqui, Baixo Amazonas, Pará. Revista de Antropologia, 44(2): 39-88. doi:10.1590/\$0034-77012001000200002.

Nugent S. 1993. Amazonia Caboclo society: an essay on invisibility and peasant economy. Berg, Oxford, UK.

PAHO. 2016. Interactive malaria statistics [online]: Available from paho.org/hq/index.php? option $=$ com_content $\&$ view $=$ article $\&$ id $=2632 \% 3$ A2010 - interactive- malaria-statistics $\&$ catid $=1617 \%$ 3Amalaria-statistics- maps\&Itemid $=21308$ lang=en.

Pink S. 2014. The visual in ethnography: photography, video, cultures and individuals. In Doing visual ethnography. SAGE Publications, London, UK. pp. 21-40.

Programa das Nações Unidas para o Desenvolvimento. 2014. Índice de desenvolvimento humano municipal (IDHM) -Amazonas [online]: Available from atlasbrasil.org.br/2013/pt/perfil_uf/ amazonas.

Ritchie J, Elam JLG, Tennant R, and Rahim N. 2006. Designing and selecting samples. In Qualitative research practice: a guide for social science students and researchers. Edited by J Ritchie, J Lewis, CM Nicholls, and R Ormston. SAGE, London, UK. pp. 77-108.

Scherer E. 2004. O Defeso e a defesa do meio ambiente. II Congresso Da Associação Nacional de Pós-Graduação E Pesquisa Em Ambiente E Sociedade and II Congresso Da Associação de Pesquisa E Pós-Graduação Em Ambiente E Sociedade. Indaiatuba, SP.

Silva HP. 2006. A saúde humana e a Amazônia no século XXI: reflexões sobre os objetivos do Milênio. Novos Cadernos NAEA, 9(1): 77-94. doi:10.5801/ncn.v9i1.58.

Straus SE, Tetroe J, and Graham I. 2009. Defining knowledge translation. Canadian Medical Association Journal, 181(3-4): 165-168. doi:10.1503/cmaj.081229. 
Warrel DA, and Giles HM. 2002. Essential malariology. 4th edition. Arnold, New York, New York.

WHO. 2015. World malaria report 2015. WHO, Geneva, Switzerland.

Woortmann K. 2008. Quente, frio e reimoso: alimentos, corpo humano e pessoas. Caderno Espaço Feminino, 19(1): 17-30.

Young A. 1982. The anthropologies of illness and sickness. Annual Review of Anthropology, 11: 257-285. doi:10.1146/annurev.an.11.100182.001353. 